\title{
Social work and food security: Case study on the nutritional capabilities of the landfill waste pickers in South Africa
}

\author{
Catherina J. Schenck, Phillip F. Blaauw, Jacoba M.M. Viljoen and Elizabeth C. Swart
}

\begin{abstract}
Food security (or the lack of it) has a direct impact on people's well-being and is of great concern to many disciplines. The study on which the article is based used Drèze and Sen's 'nutritional capability' concept as a theoretical framework to explain the food (in)security of landfill waste pickers. A cross-sectional research approach was followed, coupled with a triangulation mixed method research design. Viewing the waste pickers against the nutritional capability framework highlighted the important role that social work should play in focusing on people's capabilities within their particular context.
\end{abstract}

\section{Introduction}

For decades, countries have been preoccupied with food (in)security and (mal)nutrition, since these phenomena directly impact the daily existence and well-being of communities the world over (Kaiser, 2011; Kaiser et al., 2015; Tacoli et al., 2013). A person's nutritional status directly influences (and is influenced by) their physical and mental health and work/school performance, and is regarded as the most critical development factor in the first 3 years of a child's life (Cusick and Georgieff, 2012). A country's nutrition patterns, for example, are seen to have lasting effects on that country's health and prosperity (Cusick and Georgieff, 2012, 2016; Devereux and Waidler, 2017). Food security, in turn, is considered to be directly dependent on and sensitive to political, socioeconomic and environmental dynamics and policies globally, both nationally and locally, and does not only suggest access to, and the availability of, food (Kaiser et al., 2015; Riches, 2011). Sen (1999) concurs with this, saying that food deprivation will not be found in corruption-free countries with good governance, freedom, democracy, good planning and an independent media that monitors government policies. Hunger and food insecurity should therefore not be seen as only a family problem; it also relates to human rights and social justice, and has deep political roots (Burgess and Shier, 2016; Council on Social Work Education, 2016; Kaiser et al., 2015; Terzi, 2007). This should be of significant concern to the social work profession (Council on Social Work Education, 2016).

According to the global definition of social work, the profession plays an important role in promoting social change and development, including empowering and liberating people, based on the principles of social justice, human rights and collective responsibility 
(International Federation of Social Workers, 2014). The literature produced by social work researchers on the subject of food security has increased over the past few years, but it remains limited. Of concern is the fact that documented research findings on food (in)security in the global South have been produced by social workers from the global North (Burgess and Shier, 2016).

Despite the fact that food (in)security has been attracting growing attention, it is not clear why social workers have not actively joined the research effort. To date, their involvement has largely been confined to charitable or developmental initiatives relating to food stamps, soup/food kitchens, food parcels and food garden development programmes (Kaiser, 2011; Kaiser et al., 2015). Burgess and Shier (2016) urge social workers to become involved in facilitating greater food security, such as developing a thorough understanding of, and intervening in, food security problems at multiple levels. Educators, in turn, should include food security in their curricula. Food security studies, according to Burgess and Shier (2016), should start by first assessing the food (in)security of individuals or vulnerable groups on a micro level, while also challenging the structural and political injustices of hunger and food insecurity.

This article aims to add to the limited research conducted by social workers on food (in)security in South Africa, by investigating and assessing the food (in)security of landfill waste pickers, who are recognised as being particularly vulnerable to food shortages. The article also uses the concept of 'nutritional capability', as described by Drèze and Sen (1989), as a theoretical framework to explain the nature and extent of food (in)security among waste pickers on the landfill sites in South Africa. This is with a view to broadening people's understanding of the concept of food (in)security which, in turn, may have particular relevance for the social work profession. The article ends with suggestions for the way forward, including policies and interventions that could reverse the food insecurity problem among the vulnerable waste-picking community in South Africa.

\section{From food security to nutritional capability}

Many definitions exist for the concept of food security. The Committee on World Food Security (2012) states:

Food and nutrition security exists when all people at all times have physical, social and economic access to food, which is consumed in sufficient quantity and quality to meet their dietary needs and food preferences, and is supported by an environment of adequate sanitation, health services and care, allowing for living a healthy and active life. (p. 8)

The above definition focuses on the conditions for food security, but is silent on the position of the person within the process. Drèze and Sen (1989) argue that well-being (including food security) should be promoted through the focus being placed on the person, including the expansion and enhancement of their capabilities, opportunities, freedoms and agency. Instead of the person being a passive recipient entitled to food, this alternative approach enhances the person's agency to the extent that they become capable of taking responsibility

\section{http://repository.uwc.ac.za}


for their own food security (and well-being) - including being able to challenge unjust and discriminatory systems (Burchi and De Muro, 2016; Drèze and Sen, 1989). The concept of nutritional capability, which is based on the rights of the person and on social justice, aims to shift the focus to the person and their particular circumstances, to equalise opportunities to food security, and to enhance the capabilities of every person, on a micro and macro level, to become food secure.

In this article, the researchers argue that using the concept of nutritional capability places the field of food security at the centre of social work and social development, whose focus is similarly to increase the opportunities and capabilities of people on a macro, meso and micro level (International Federation of Social Workers, 2014). The article asserts that the more a person's opportunities and capabilities are developed, the more food secure the person will be (Devereux and Waidler, 2017; Drèze and Sen, 1989; Tacoli et al., 2013).

The next section provides an overview of waste picking and waste pickers on the landfill sites in South Africa. This is followed by an explanation of each of the five dimensions of the waste pickers' nutritional capabilities on these selected landfill sites. The five dimensions are as follows:

(1) the waste pickers' access to food and food availability, (2) their food utilisation, (3) the capabilities that enable them to access sufficient food, (4) their agency and (5) the stability and sustainability of their access to food.

The analysis of nutritional capability in this article therefore mainly constitutes a micro assessment of the waste pickers; however, the macro context is also recognised.

\section{Waste pickers on the landfills in South Africa}

The last decade has seen an increasing amount of research being conducted on waste picking, an activity that provides people with an opportunity to make a living in the informal economy. International research on waste pickers includes studies by Nzeadibe and Mbah (2015), Mbah and Nzeadibe (2016), Medina (2007) and Dias and Samson (2016). National research on the activities of landfill and street waste pickers includes studies by Chvatal (2010), Samson (2012), Schenck et al. (2012), Viljoen (2014) and Mamphitha (2011).

From earlier research, it is evident that official waste management systems in many cities cannot survive without the myriad waste pickers who ply their trade, even though they do not receive any formal support (Roberts, 2013; Van Heerden, 2015). The waste pickers often form the basis of the waste recycling industry at no cost to local authorities, central government or residents (Gerdes and Gunsilius, 2010; Mbah and Nzeadibe, 2016). In South Africa, it is estimated that waste pickers save municipalities up to R750 million per year and furthermore help to conserve landfill space (Farber, 2016). Despite the waste pickers' contribution to recycling and the economic and environmental benefits they bring to the municipalities, waste pickers are not recognised in national and provincial policies, nor are they included in decision making surrounding the management of land-fill sites. This leaves 
them at the mercy of provincial and municipal structures and/or landfill managers/contractors. The management strategies of landfills either exclude waste pickers, depriving them of a livelihood, or allow them onto the site, but the management thereof could range from good to dismal. The waste management strategies clearly have a major impact on the quality and sustainability of waste pickers' livelihoods (Blaauw et al., 2015; Nzeadibe and Mbah, 2015; Reyneke, 2016; Samson, 2012; Schenck et al., 2012).

Studies on informal workers in South Africa should always be examined against the backdrop of the official unemployment rate of 27 percent (Statistics South Africa, 2016), the phenomena of deeply entrenched poverty and inequality, and the high numbers of people who are unskilled or have limited qualifications and thus limited prospects. For these people the informal economy offers, in many instances, the only barrier-free option to earn an income and acquire access to food (Skinner and Haysom, 2016).

\section{Methodology}

The case study of the landfill waste pickers used a cross-sectional approach, coupled with a triangulation mixed method design (Creswell, 2007). The triangulation mixed method design is characterised by two or more methods used to confirm, cross-validate and support findings within a study (Creswell, 2003). The interdisciplinary team ${ }^{1}$ of researchers used both qualitative and quantitative data in order to arrive at the fullest understanding of the phenomenon under investigation (Creswell, 2003).

Nine (six rural and three urban) landfill sites, situated in four of the nine provinces in South Africa, were sampled in consultation with the Centre of Excellence (CoE) in Food Security (which funded the project) so as to coincide with other CoE studies being performed in the same areas. Before the fieldwork commenced, members of the research team visited the landfill sites to determine whether they would be accessible to the fieldworkers, to obtain permission from the municipalities/local authorities to carry out the work, to identify the language(s) spoken by waste pickers on the landfill sites in order to prepare data collection instruments and to recruit suitable fieldworkers. ${ }^{2}$

Three sets of data were collected simultaneously by trained fieldworkers. First, socioeconomic data were collected using a questionnaire containing quantitative and openended, exploratory qualitative questions. Second, nutritional data were collected by means of a 24-hour recall procedure - using a standardised record form and a dietary intake toolkit to assist with quantification - as well as anthropometrics measurements (height and weight) using calibrated equipment and a standardised methodology, as described by Lee and Nieman (2013). Third, semi-structured individual and group interviews were conducted. General observations were also recorded and photographs taken during the data collection process.

All available and willing waste pickers were interviewed on the days the researchers visited the various landfills. Trained fieldworkers conducted the interviews in the presence of the 
researchers who assisted the fieldworkers if any problems occurred. The fieldwork commenced in April 2015 and was completed in April 2016. A total of 373 waste pickers were interviewed. Table 1 reflects the number of interviews conducted on each of the landfill sites.

The sample sizes of waste pickers interviewed showed significant coverage of the estimated total number of waste pickers on site on the days of the interviews.

\section{Results}

The results are presented within the nutritional capability framework, as outlined by Drèze and Sen (1989) and Burchi and De Muro (2016).

Table I. Number of completed interviews conducted on each landfill site.

\begin{tabular}{lccc}
\hline Landfill site & $\begin{array}{l}\text { Estimated number of } \\
\text { waste pickers on site on } \\
\text { the day of the interviews }\end{array}$ & $\begin{array}{l}\text { Number of } \\
\text { waste pickers } \\
\text { interviewed }\end{array}$ & $\begin{array}{l}\text { Percentage of } \\
\text { waste pickers } \\
\text { interviewed (\%) }\end{array}$ \\
\hline ST (rural) & 50 & 46 & 92 \\
OU (rural) & 50 & 32 & 64 \\
BN (urban) & 60 & 38 & 63 \\
BS (urban) & 60 & 49 & 81 \\
BO (rural) & 40 & 39 & 97 \\
PR (urban) & 200 & 98 & 49 \\
BR (rural) & 40 & 31 & 77 \\
VR (rural) & 30 & 23 & 76 \\
PO (rural) & 20 & 17 & 85 \\
Total & 550 & 373 & 74 \\
\hline
\end{tabular}

Source: Survey data.

\section{Dimension 1: Waste pickers' access to food and food availability}

Food availability refers to the effective or continuous supply of food at both the national and household level, while food access includes the ability (access and affordability) to acquire sufficient food (Burchi and De Muro, 2016). Food access addresses whether households or individuals have enough resources and capabilities to acquire appropriate quantities of quality food, either through buying or producing the food themselves. South Africa is regarded as being nationally food secure in view of the country's own production and a favourable import/export balance, which results in sufficient food for the people (Du Toit, 2011). Yet 13 percent of the population still suffer from hunger (Statistics South Africa, 2016).

Waste pickers are unemployed people who make a living by collecting and selling waste. On the landfills, the waste pickers have two means of accessing food. They collect and sell waste in order to buy food, or they collect food that has been thrown away by households, factories or shops. The more waste they can collect and sell, the more money they will earn to buy food. 
The income earned by landfill waste pickers fluctuates daily. For this reason, the waste pickers' actual income in the week before the interview, the income earned in a good week and the income earned in a bad week were all recorded. The self-reported income of the landfill waste pickers on the different landfills in the week before the interview is summarised in Table 2.

The landfill income data offer perspectives on the differences in income among the landfill waste pickers in the different regions. It further highlights the vulnerability of the waste pickers in the rural areas, such as BO and OU, compared with those in urban areas like $\mathrm{BN}$. The reason for the low income earned on the (urban) PR landfill site is that there is an additional layer of waste buyers on the site who buy from the waste pickers and sell to the buy-back centres. This practice reduces the income earned by the landfill waste pickers. What is important to note is the extreme vulnerability of the waste pickers to adverse conditions. For example, their income is directly affected when they are sick and when there is harsh weather, including rain and extreme cold.

As is the case with many other informal economy activities in South Africa, the landfill waste-picking community is male dominated. Table 3 provides a gender-based comparison at the different landfill sites.

Table 2. Income for week prior to the interview per landfill $(n=359)$.

\begin{tabular}{lrrrrrr}
\hline Landfill site & $N$ & Minimum & Maximum & Mean & Median & $\begin{array}{c}\text { Standard } \\
\text { deviation }\end{array}$ \\
\hline BN (urban) & 37 & 0 & 1800 & 707.03 & 600 & 426.3597 \\
BS (urban) & 50 & 0 & 2000 & 601.20 & 600 & 428.7744 \\
BO (rural) & 30 & 0 & 750 & 318.23 & 300 & 151.0886 \\
BR (rural) & 31 & 0 & 1200 & 304.23 & 300 & 233.3189 \\
PR (urban) & 92 & 0 & 2000 & 380.41 & 300 & 295.0036 \\
OU (rural) & 33 & 10 & 1520 & 223.79 & 190 & 257.4812 \\
PO (rural) & 17 & 100 & 2000 & 711.76 & 500 & 525.7523 \\
ST (rural) & 45 & 0 & 1800 & 482.22 & 400 & 393.3012 \\
VR (rural) & 24 & 120 & 1200 & 452.11 & 354.35 & 268.6425 \\
Total & 359 & 0 & 2000 & 451.90 & 350 & 369.5422 \\
\hline
\end{tabular}

Source: Survey data. 
Table 3. Gender distribution (percentages).

\begin{tabular}{|c|c|c|c|c|c|c|c|c|c|}
\hline & ST & OU & $\mathrm{PO}$ & VR & $\mathrm{BO}$ & $\mathrm{BR}$ & $\mathrm{BN}$ & BS & PR \\
\hline Male & 78 & 73 & 100 & 79 & 30 & 9 & 59 & 68 & 47 \\
\hline Female & 20 & 27 & 0 & 21 & 70 & 91 & $4 I$ & 32 & 53 \\
\hline Other & $2^{a}$ & & & & & & & & \\
\hline Total & 100 & 100 & 100 & 100 & 100 & 100 & 100 & 100 & 100 \\
\hline
\end{tabular}

Source: Survey data.

a'Other' refers to two transgender waste pickers who did not indicate whether they were male or female. On closer observation, it was concluded that both were men dressed as women.

On almost all the landfill sites men comprised the majority, except on the landfill sites in BO where 70 percent of the waste pickers were women and in BR where 91 percent were women. The waste company managing the landfill site in PO took the decision not to allow women on the site in order '... to make things less complicated'. In general, the male waste pickers can earn more than the female waste pickers as they are able to collect and carry heavier items, such as heavy scrap metals, for which they can earn more.

The importance of the gender-based findings is that waste picking is accessible to both men and women if allowed by the municipalities' waste management departments. This reinforces waste pickers' dependency on the decisions of the landfill management and their possible exclusion from certain landfills, which would deprive them of a livelihood. It was observed that on some landfills, the safety of women is an issue. Some respondents shared stories of being robbed and raped by the (young) men, which adversely affects their earnings. In addition, Phillips (2009) emphasises that women are more directly affected by food insecurity since they may decide to stop eating, just to feed their families. Clearly, being excluded from certain landfills and/or being exploited while trying to earn a living could negatively impact a family's food security.

Just over 42 percent of the respondents in the survey were younger than 35 years, while the average age of respondents was 39 years, with the youngest aged 18 years and the oldest aged 71 years. What is important from this finding is that older people are not excluded. If this were formal employment, they would not be able to collect waste on the landfills as the retirement age in South Africa ranges from 60 to 65 years. Working informally often has the benefit of fewer barriers to accessing a 'job' and thus the ability to earn an income. 


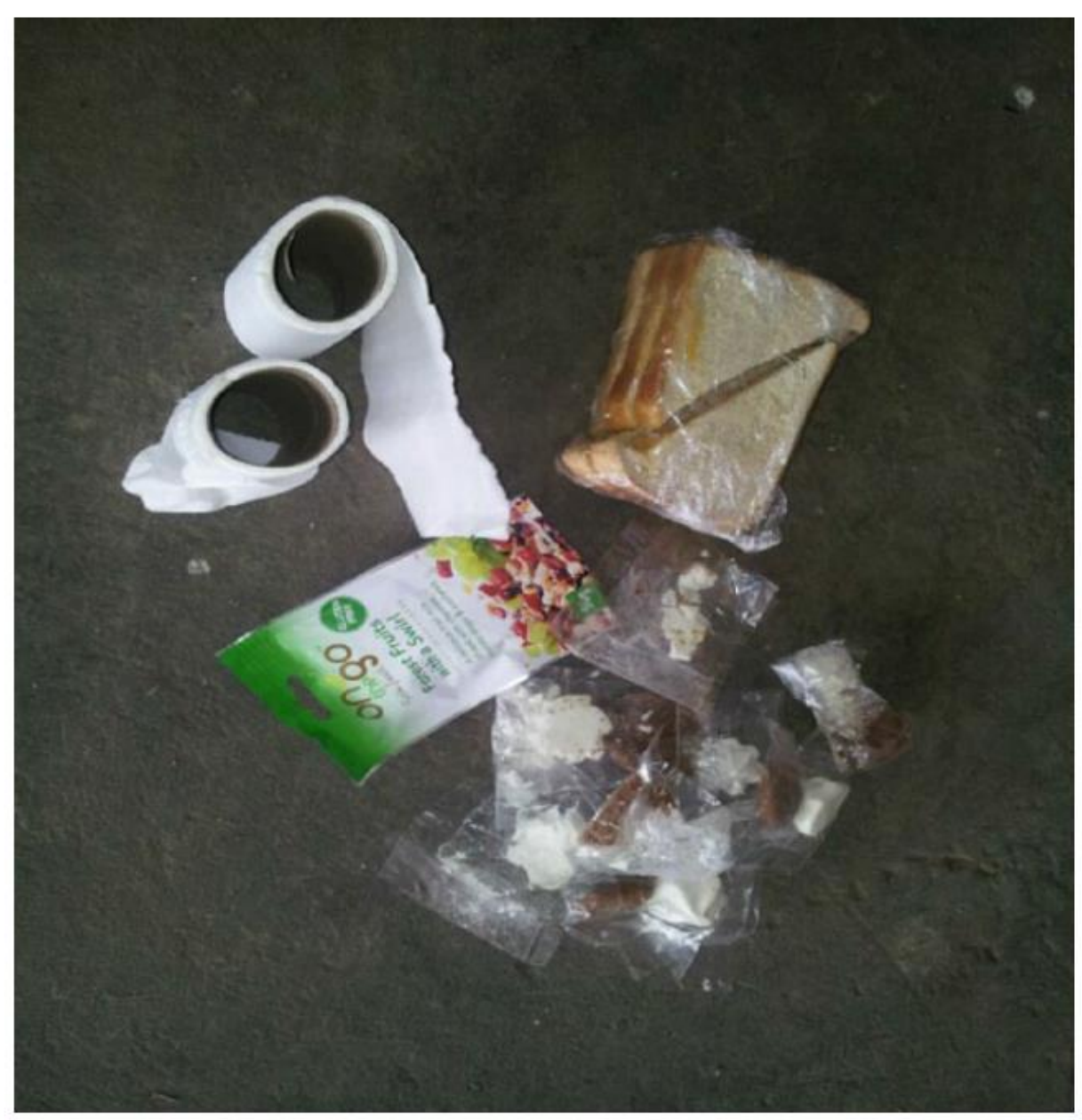

Figure I. Food picked up from the landfills. Photo: Joy Williams.

The landfill site was the only source of income and livelihood for 55 percent of the waste pickers. These waste pickers indicated that they had no other source of income in the family.

In addition to the recycling activities from which waste pickers are able to earn a living, the landfills are also sources of food, clothes, furniture, and household and other accessories. For families such as those on the OU landfill, the food they acquire there is so important that the landfills have come to be referred to as the 'oumies' or 'old madam', meaning the provider of all their needs. Two of the landfills cover food from shops, according to the regulations. However, waste pickers can also access food from household waste.

On the landfills where the waste pickers can access food, they are allowed to take the food before it is covered, in line with legislation. In some instances, waste pickers reported that restaurants or fast food chains occasionally delivered 'end of day' or 'expiry date' products to them for consumption. To prevent contamination, restaurants or fast food chains pack the food in plastic containers and do not mix it with the rest of the waste. Similarly, some retail shops and butcheries indicate to the waste pickers which food is still edible, and which is

\section{http://repository.uwc.ac.za}


not. Food that is no longer safe will be buried. The waste pickers told the researchers that they know which food is rotten. They also showed some of the food recovered which was still 'good' for consumption (Figure 1).

On the OU or 'oumies' landfill site, which is situated close to a township, the availability of food also attracts mothers and children from the township. Late in the afternoon, mothers and children come to the landfill to collect food and wood for the evening meal. Thus, this landfill is providing for the needs of more people than just the waste pickers.

There is a meat-processing factory in the vicinity of the landfill in $\mathrm{BO}$ and the waste pickers reported that they regularly had access to 'Russian' sausages. Two of the landfills also receive food from the military base in the area and university residences, over and above the normal household waste.

Table 4. Food items collected on the landfills $(n=179)$.

\begin{tabular}{lcc}
\hline Food items & $N$ & $\%$ \\
\hline Meat/chicken & 107 & 59.8 \\
Bread/buns & 77 & 43.0 \\
Fruit/vegetables & 61 & 34.1 \\
Tinned food & 27 & 15.1 \\
Maize & 25 & 14.0 \\
Rice/pasta/dry food/soup/spices & 21 & 11.7 \\
Juice/drinks/cold drinks & 15 & 8.4 \\
Milk/dairy/eggs & 18 & 10.1 \\
Anything still good enough to eat & 11 & 6.1 \\
Coffee/tea/sugar & 10 & 5.6 \\
Sweets/chocolates/chips/snacks/cakes/pies & 10 & 5.6 \\
Fish & 3 & 1.7 \\
Groceries/toiletries & 8 & 4.5 \\
Alcohol & 1 & 0.6 \\
\hline
\end{tabular}

Source: Survey data.

Food from the military base and university residences is usually packed in disposable containers, whereas edible household waste is recovered from the general waste.

Table 4 gives an indication of the types of food collected on the landfills for consumption purposes.

The waste pickers indicated that they received food practically every day, but there were some days when there was little or no food depending on the areas from which the local authority waste removal trucks collected waste. If they collected food from the more affluent areas, more food was available than when the trucks collected from the poorer parts of the town/city. Although the waste pickers could either find food on the landfill site or buy food 
with the income they earned, some indicated that there were days when they still went hungry.

Almost 33 percent of the waste pickers interviewed indicated that on certain days of the month, they did not have access to food. Interestingly, most of the waste pickers who went hungry worked on the PR site, which is in an urban area. This lack of food could possibly be linked to the lower incomes they earned in the face of the extra layers of buyers and sellers on the landfill, which did not occur on the other landfills included in the study.

\section{Dimension 2: Food utilisation}

The food accessed at the landfill site cannot be regarded as secure or sustainable. Furthermore, not all the food accessed can be used. For example, it carries the risk of contamination from microorganisms, which could cause food-borne gastroenteritis. Given the lack of resources such as access to running water and toilets (see Table 5), it is highly unlikely that the waste pickers would have the means to follow food safety principles, although they confirmed that they seldom got sick and were knowledgeable about how to make a distinction between edible and rotten food. Various waste pickers reported that they cooked the meat they recovered from the landfill before eating it. Some showed the researchers the meals they cooked on the landfill, thus preserving the food until they went home to feed their families. If the food remained raw, it might rot. Figure 2 provides an example of a cooked 'stew'.

Table 5. Access to basic amenities while collecting waste.

\begin{tabular}{lrrr}
\hline Basic needs & No & Yes & Total \\
\hline Drinking water & 80 & 284 & 364 \\
Toilet & 180 & 182 & 362 \\
\hline
\end{tabular}

Source: Survey data. 


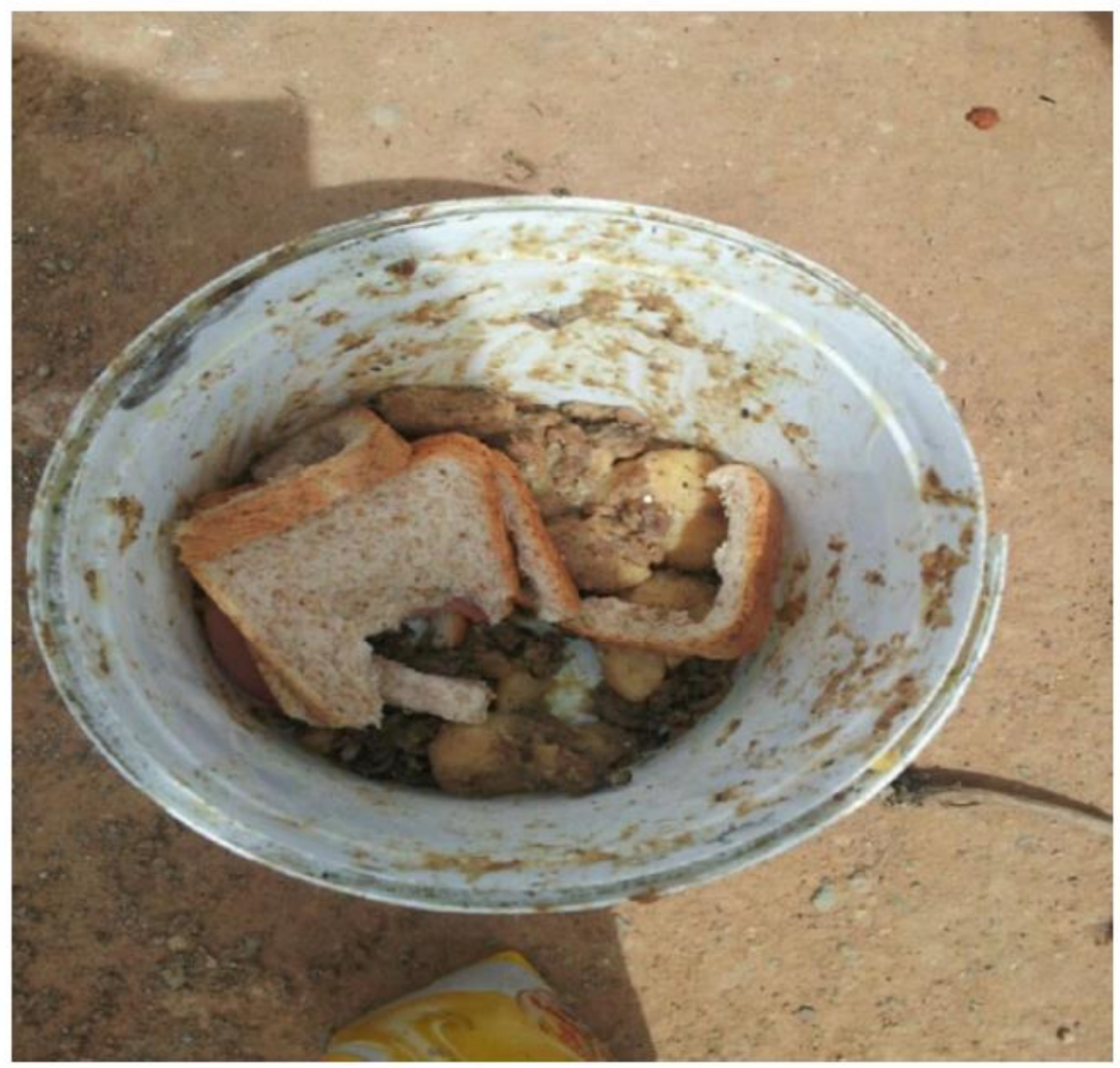

Figure 2. 'Stew' cooked on the landfill where everybody contributes. Photo: Joy Williams.

Other foodstuffs like bread are consumed as is (Figure 3). An initial review of the 24-hour recall intake instrument revealed that many waste pickers consume only one meal a day, with some reporting that they consumed nothing other than water for a whole day. This was confirmed by the data in Table 6 .

The majority of the research population seemingly had some sort of access to drinking water while collecting waste at the landfill sites. This was mostly from taps or tanks at the site. Of concern is the fact that almost half the respondents said that they do not have access to toilet facilities while collecting waste, which means that they have to use the veld or bushes close to the landfill. The fact that waste pickers are not officially recognised or supported implies that municipalities are not obliged to provide them with water and sanitation.

\section{Dimension 3: Capabilities}

Food security is about having the means to access and prepare sufficient and nutritious food. If one has good health, education/skills, a job, and a good network and relationships, it will be possible to access food either by buying it or growing it, thereby creating a safety net (Burchi and De Muro, 2016; Drèze and Sen, 1989). 


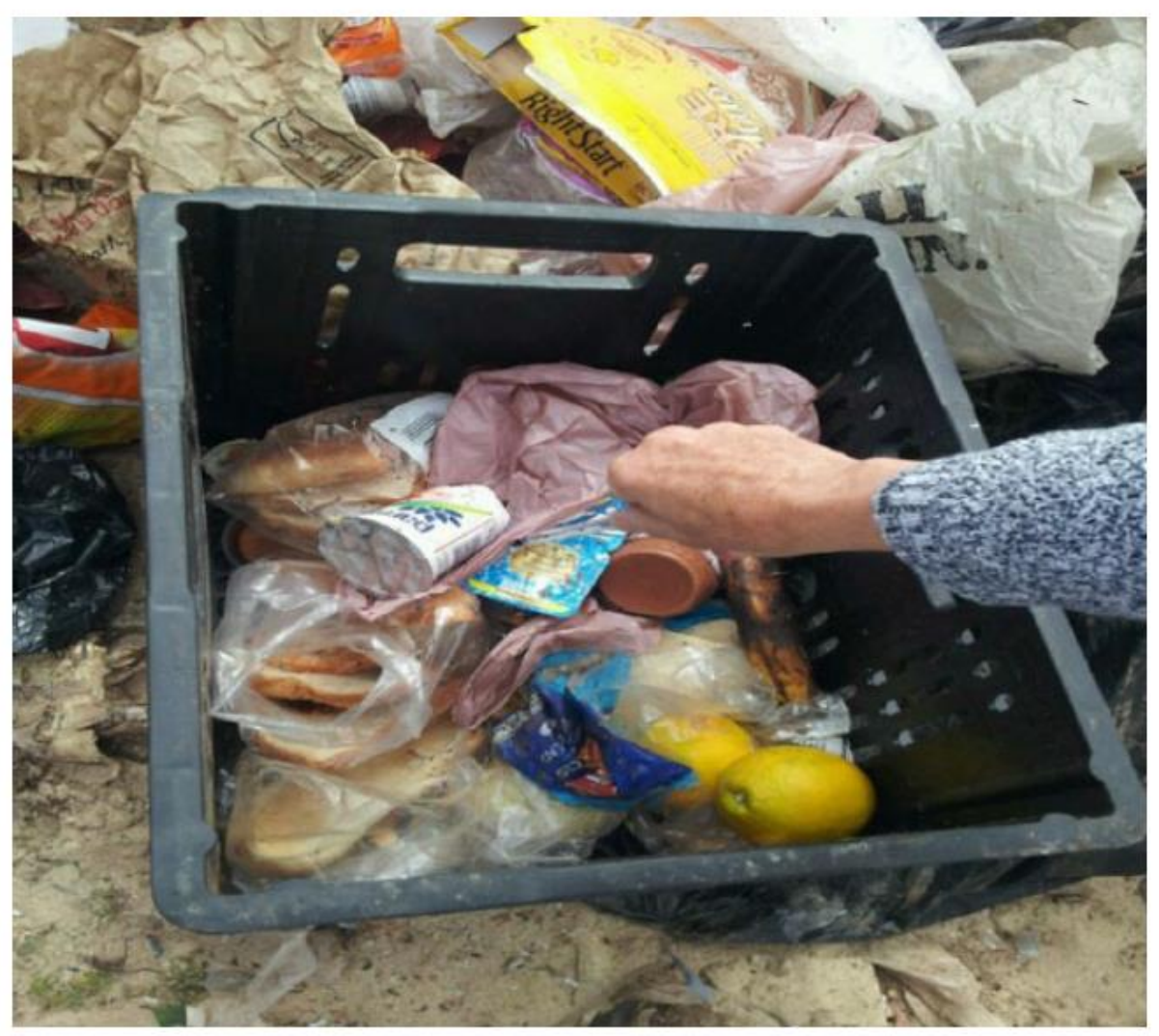

Figure 3. Food recovered from the landfill.

Photo: Joy Williams.

Table 6. Days without food during the last month.

\begin{tabular}{|c|c|c|c|c|c|}
\hline $\begin{array}{l}\text { Landfill } \\
\text { site }\end{array}$ & I-3 days & 4-5 days & 6-10 days & $\begin{array}{l}\text { More than } \\
\text { I0 days }\end{array}$ & Total \\
\hline $\mathrm{BN}$ & I & 0 & 0 & 0 & I \\
\hline BS & 6 & 2 & 3 & 0 & 11 \\
\hline $\mathrm{BO}$ & 7 & I & I & 2 & 11 \\
\hline BR & 4 & 2 & 2 & 0 & 8 \\
\hline PR & 26 & 9 & 7 & 2 & 44 \\
\hline OU & 7 & 5 & 3 & 3 & 18 \\
\hline $\mathrm{PO}$ & 2 & 0 & 0 & I & 3 \\
\hline ST & 13 & 2 & 3 & 2 & 20 \\
\hline VR & 4 & 2 & 0 & I & 7 \\
\hline Total & 70 & 23 & 19 & II & 125 \\
\hline
\end{tabular}

Source: Survey data.

Figure 4 shows the highest school qualifications attained by the waste pickers in the study. 
Of the total respondents, 9 percent did not have any schooling at all, while 43.5 percent had obtained some secondary level education, ranging from Grade 8 to Grade 11. Fewer than 8 percent of respondents had completed matriculation.

The results broadly correspond with the findings from other studies on South Africa, such as those of McLean (2000a, 200ob), Sentime (2011), Schenck and Blaauw (2011a, 2011b), Viljoen (2014), Van Heerden (2015) and Schenck et al. (2016), which concluded that the educational qualifications of waste pickers (street and landfill) in South Africa are very low. This educational deficit is one of the main reasons for people engaging in waste picking and not (and probably never) being able to acquire formal employment.

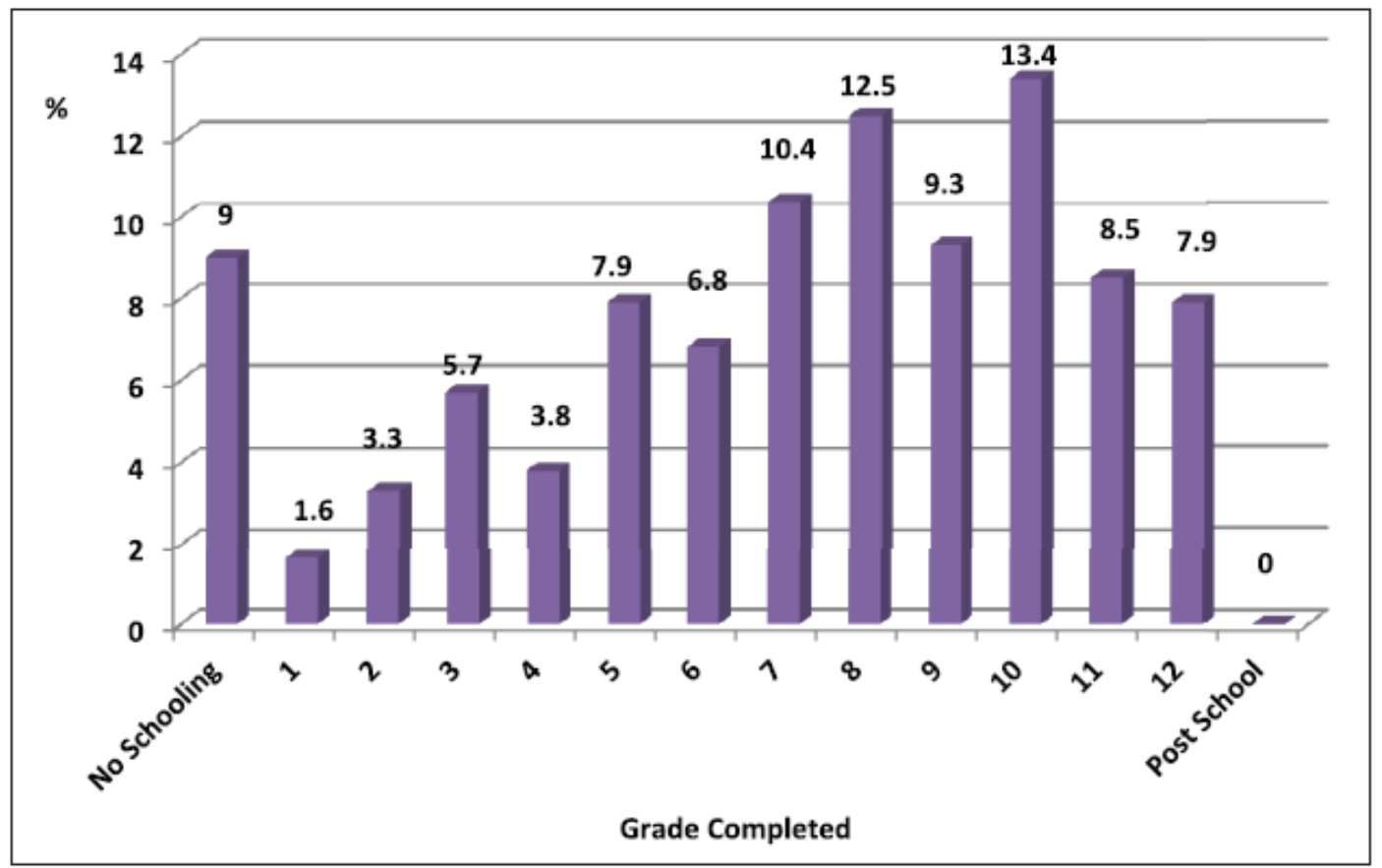

Figure 4. Highest school qualification of landfill waste pickers.

Source: Survey data.

The results from this study emphasise how the educational shortcomings of the waste pickers is depriving them of an opportunity to secure decent and sustainable jobs and/or incomes. Being mainly unskilled, their prospects of acquiring jobs in the formal sector are very poor, except for low-level manual work, which will keep them in a low-income position and render them powerless. Waste picking offers them a low-barrier opportunity (in fact, the only option, according to some of those interviewed) to earn a living and put food on the table (Mamphitha, 2011; Schenck et al., 2012; Viljoen, 2014). Even though the waste pickers indicated that they would like to have a formal job, this will not happen unless concerted efforts are made to re-train and up-skill the younger waste pickers. Bali et al. (2013) are of the opinion that, globally, the views about securing formal jobs would have been realistic 30 years ago, but this is no longer the case, even among more qualified people. Formal workplaces, job security and workplace unions are gradually disappearing and are being 
replaced by models that epitomise 'flexibility'. The large numbers of self-employed and informal workers are a growing phenomenon that is here to stay.

The waste pickers shared with the researchers the fact that financial difficulties or poverty were the most prominent reasons for their not completing matriculation. This was exacerbated further by family problems, such as the death or illness of one or both parents. The family often had insufficient money to afford school fees or the respondents had to search for work to support their parents and/or other family members. Very few waste pickers left school early by choice. The lack of family and/or financial support can therefore be considered to be the main cause of many waste pickers not attaining a formal secondary school qualification (Schenck and Blaauw, 2011a; Schenck et al., 2016; Viljoen, 2014).

\section{Dimension 4: Agency}

Agency refers to people's ability to reflect, to take decisions, to act independently, or to pursue or achieve their own goals (Burchi and De Muro, 2016; Sen, 1999). Blunden (2004) equates the concept of agency with having the power of self-determination. Burchi and De Muro (2016) view the person who acts by taking responsibility for their own selfemployment as one who has agency.

Table 7. Total, mean and median number of dependants $(n=33 \mathrm{I})$.

\begin{tabular}{lclllll}
\hline & $N$ & Minimum & Maximum & Mean & Median & $\begin{array}{l}\text { Standard } \\
\text { deviation }\end{array}$ \\
\hline Dependants & 1178 & 0 & 15 & 4 & 3 & 2.220839 \\
Children & 764 & 0 & 12 & 3 & 2 & 1.668236 \\
Children under 18years & 521 & 0 & 9 & 2 & 2 & 1.300138 \\
\hline
\end{tabular}

Source: Survey data.

However, Lindell (2010) emphasises that agency includes autonomy and power, which for these informal workers are limited. Although the landfill waste pickers are working for themselves and making a living, Lindell (2010) explains that they are still deprived of agency as long as they do not participate in the management of the landfills, which in turn affects their income, livelihoods and well-being.

The agency of the waste pickers is further illustrated in the survey results, which show that they care for (on average, four) dependants and assist and support each other informally in a variety of ways on the landfill sites. For example, they help each other to collect, load and carry the waste, they share their food and they look after one another when sick. They are also fiercely independent and individualistic when it comes to generating their own income. They are for the most part not interested in working together formally in for example a cooperative, and definitely not interested in sharing their earnings (Blaauw Schenck et al., 2016; Schenck et al., 2012; Van Heerden, 2015; Viljoen, 2014). 
In most cases, the income of waste pickers has to support their families and themselves. Among the 331 waste pickers in the study, a total of 1178 dependants relied on the waste pickers' income (see Table 7). Most (764 or 64.9\%) of these dependants were children, with $521(68.2 \%)$ of these children being under 18 years of age. Children younger than 18 years might represent an additional source of household income as a result of the government's child support grant.

Half the waste pickers with dependants had to support a family of four, including themselves. Larger households need more money to support everyone, but here more members of the house-hold can contribute to the pool of income. However, only 81 landfill waste pickers indicated that they, or one of their dependants, had additional sources of income. These results imply that food security for the waste pickers is subject to even greater stress than previously thought.

A further dimension of agency is the ability to participate in societal affairs and have a voice. Possible recognition afforded waste pickers by the formal waste management system and participation in planning are non-existent on the landfills covered in the study. Researchers and practitioners tend to emphasise the bravery and entrepreneurial capacities of the people, but as Lindell (2010) states, '... ultimately the aesthetic framing of the informal sector silences the voices and experiences of the informal workers' (p. 1). None of the municipalities or companies managing the landfills has made provision for the waste pickers to participate in any form of decision making regarding the management of the landfills. On the ST landfill, the researchers found a committee that worked closely with the manager, but the committee's decisions were minor and the committee members were merely the intermediary voice between the waste pickers and the managers.

\section{Dimension 5: Stability and sustainability}

With reference to the research data, waste-picking practices aimed at earning a living and accessing food (buying or growing food, or picking it up from the landfill) do not offer sustainable food security to the waste pickers. Nevertheless, waste picking does offer some (albeit rather irregular) access to food - food that waste pickers would not have if they were not contributing to the recycling industry. Survivalist activities depend on the viability and management of the particular land-fill site, and the local government.

Waste pickers in general are vulnerable to an array of exogenous shocks in respect of which they have neither control nor any recourse or remedy. Some of the persistent risks and insecurities are linked to the fact that waste pickers are not acknowledged in government policies and consequently there are no guidelines for municipalities on how to work alongside the waste pickers in the waste management system. In a study conducted by Roberts (2013) on the landfills in the Free State province, it states that where there are policies and guidelines on how landfills should be managed, many municipalities cannot even meet the minimum health and environmental criteria. They are literally 'dump sites' (Roberts, 2013). It is therefore up to the landfill manager, operator or decision makers at the municipalities to decide how the waste pickers should be managed.

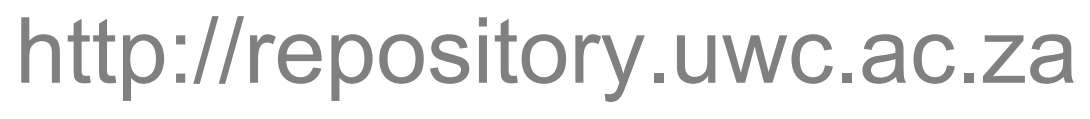


It appears from the results of the study that in general the municipal workers on the landfills treat the waste pickers well; however, that does not protect them from being exploited or periodically barred from or refused entry to the landfills.

The waste pickers' access to waste and food (which strongly influence their livelihoods) is also at the mercy of extreme heat, cold and rain, which may hinder their ability to collect waste and food productively. For example, they earn less for wet paper and cardboard boxes (Viljoen, 2014). Yet even on extremely hot, cold or rainy days, the waste pickers still collect waste and cope with the prevailing conditions (Van Heerden, 2015). None of the landfills provide any form of protection against rain or sun where waste could be stored or sorted, although some self-made structures were found.

\section{Final discussion and conclusion}

For Blunden (2004), Sen is not someone inclined towards offering a single solution to social problems; rather he provides a strong, unitary theme or theory that provides the foundation for socially driven thoughts and actions/interventions. In the present article - with reference to Drèze and Sen's (1989) framework, and further explained by Burchi and De Muro (2016) the unitary and logical theory underpinning the food security of the waste pickers has focused on their nutritional capabilities, from the micro to the macro level. Focusing on the nutritional capabilities of the waste pickers is multidisciplinary and human and people centred, highlighting the capabilities (or lack of capabilities) and agency of the waste pickers to access and prepare nutritional food. These capabilities include micro- and meso-level interventions, aimed at people within their particular contexts, and macro-level interventions aimed at challenging unjust systems and policies (or the absence of policies and systems) which rob people of food security. The role of social work is clear in this regard. The study has also illustrated how intergenerational poverty and family problems prevent children from, for example, completing their schooling, which in turn places them at a disadvantage in society, that is, unable to enter formal employment and earn a stable income, and having limited agency. It has highlighted the broadly unequal and socially unjust socio-political and socioeconomic environment in South Africa, characterised by high unemployment, inequality, ineffective education and the lack of support systems or safety nets, all of which deprive people of the freedom to live the life they value. Riches (2011) states that the existence of food banks, for example, are symptoms and symbols of broken safety nets, failing policies and the lack of socially responsible citizens. To enhance people's nutritional capabilities, social work needs to take up its position alongside those food-insecure and other professions whose potential is eroded by ongoing injustices.

Social work should focus on enhancing the dignity of waste pickers by advocating and ensuring access to water, shade and toilet facilities, to name but a few measures. These will make a significant difference in the waste pickers' daily lives. Social work should also engage in discussions and debates with other professionals dealing with aspects of livelihood and capabilities, such as nutritionists, agricultural production educators and health service providers, to put the spotlight on the vulnerability of groups such as waste pickers and to 
advocate for more inclusive service delivery and the creation of more enabling environments On another level, social work can focus on enhancing the educational and social capabilities of waste pickers, including how they access waste, food, and social and health services. Alternative sources of food could be facilitated for the waste pickers and their families, such as food gardens. But above all, it is important to ensure that the voices of the waste pickers are heard by listening to them intently and deciding with them what their priorities are and how their capabilities can be improved.

The social work profession can bring relevant stakeholders to the table, especially those who hold the power (politically and socially) and are in a position to influence policy and create platforms for advocacy and dialogue. Everyone, though, has a responsibility to create caring societies, particularly with the help of civil organisations, and to hold governments accountable for good governance that will benefit all classes of people in South Africa, especially the currently marginalised. To conclude, it is appropriate to remember the view of Riches (2011), which is that compassion and collective action are insufficient without social justice.

\section{Funding}

This research/study was made possible thanks to funding by the DST-NRF Centre of Excellence in Food Security, South Africa.

\section{Notes}

1. The team included researchers from social work (PI), economy and nutrition.

2. South Africa has 11 official languages. 


\section{References}

Bali, N., M.A. Chen and R. Kanbur (2013) Bridging Perspectives: The Cornell-SEWAWIEGO Exposure Dialogue Programme on Labour, Informal Employment and Poverty. Ahmedabad, India: SEWA Academy.

Blaauw, P.F., J.M.M. Viljoen, C.J. Schenck and E.C. Swart (2015) 'To "Spot" and "Point": Managing Waste Pickers' Access to Landfill Waste in the North West Province', Africagrowth Agenda 12(2): 18-21.

Blunden, A. (2004) 'Sen on Participation'. Available online at: http://ethicalpolitics.org/reviews/senparticipation.htm (accessed 10 December 2016).

Burchi, F. and P. De Muro (2016) 'From Food Availability to Nutritional Capabilities: Advancing Food Security Analysis', Food Policy 60: 10-9.

Burgess, D. and M.L. Shier (2016) 'Food Insecurity and Social Work: A Comprehensive Literature Review', International Social Work. Epub ahead of print 12 November. DOI: $10.1177 / 0020872816672519$.

Chvatal, J. (2010) 'A Study of Waste Management Policy Implications for Landfill Waste Salvagers in the Western Cape', Master's Dissertation, University of Cape Town, Cape Town, South Africa.

Committee on World Food Security (2012) 'Thirty-Ninth Session, Rome, Italy, 15-20 October 2012, Item V.a'. Available online at: http://www.fao.org/docrep/meeting/o26/MD776E.pdf (accessed 8 August 2016).

Council on Social Work Education (2016) 'Understanding Food Security: Human Rights and Social Work Implications'. Available online at: https://www.cswe.org/Centers-Initiatives/Centers/International-

KAKI/News/Understanding-Food-Insecurity-Human-Rights-and-(1) (accessed 25 January 2017).

Creswell, J. (2003) Research Design: Qualitative, Quantitative and Mixed Methods Approaches. Thousand Oaks, CA: SAGE.

Creswell, J. (2007) Qualitative Inquiry and Research Design: Choosing from Five Approaches. London: SAGE. Cusick, S.E. and M.K. Georgieff (2012) 'Nutrient Supplementation and Neurodevelopment: Timing Is the Key', Archives of Pediatric and Adolescent Medicine 166(5): 481-2.

Cusick, S.E. and M.K. Georgieff (2016) ‘The First 1,00o Days of Life: The Brain's Window of Opportunity'. Available online at: https://www.unicef-irc.org/article/958/ (accessed 12 December 2016).

Devereux, S. and J. Waidler (2017) 'Why Does Malnutrition Persist in South Africa Despite Social Grants?', Food Security SA Working Paper Series No. 001, January. Bellville, South Africa: DST-NRF Centre of Excellence in Food Security.

Dias, S. and M. Samson (2016) Informal Economy Monitoring Study Sector Report: Waste Pickers.

Cambridge, MA: Women in Informal Employment: Globalizing and Organizing (WIEGO). Drèze, J. and A. Sen (1989) Hunger and Public Action. Oxford: Oxford University Press.

Du Toit, D.C. (2011) 'Food Security by Directorate Economic Services. Production Economics Unit', Department of Agriculture, Forestry and Fisheries, South Africa.

\section{http://repository.uwc.ac.za}


Available online at: http://www.nda. agric.za/docs/GenReports/FoodSecurity.pdf (accessed 10 April 2017).

Farber, T. (2016) 'Meet the Bin Scavengers Saving South Africa R750 Million a Year'. Available online

at: http://www.timeslive.co.za/sundaytimes/stnews/2016/05/o8/Meet-the-binscavengers-saving-SA- R750-million-a-year (accessed 4 May 2017).

Gerdes, P. and E. Gunsilius (2010) The Waste Experts: Enabling Conditions for Informal Sector Integration in Solid Waste Management: Lessons Learnt from Brazil, Egypt and India. Eschborn: Deutsche Gesellschaft für Technische Zusammenarbeit (GTZ).

International Federation of Social Workers (2014) 'Global Definition of Social Work'. Available online at: http://ifsw.org/get-involved/global-definition-of-social-work/ (accessed 4 May 2017).

Kaiser, M.L. (2011) 'Food Security: An Ecological-Social Analysis to Promote Social Development', Journal of Community Practice 19(1): 62-79.

Kaiser, M.L., S. Himmelheber, S. Miller and R.A. Hayward (2015) 'Cultivators of Change: Food Justice in Social Work Education', Social Work Education 34(5): 544-57.

Lee, R.D. and D.C. Nieman (2013) Nutritional Assessment. Boston, MA: McGraw Hill.

Lindell, I. (2010) Africa's Informal Workers: Collective Agency, Alliances and Transnational Organisations in Urban Africa. London: Zed Books.

McLean, M. (2000a) 'A Personal Profile of Some of the Informal Collectors in Central Durban - A Case Study', Society in Transition 31(1): 1-9.

McLean, M. (200ob) 'Informal Collection: A Matter of Survival Amongst the Urban Vulnerable', Africanus 30(2): 8-26.

Mamphitha, D. (2011) 'The Role Played by Subsistence Waste Pickers in Recycling', Master's Dissertation, University of Pretoria, Pretoria, South Africa.

Mbah, P.O. and T.C. Nzeadibe (2016) 'Inclusive Municipal Solid Waste Management Policy in Nigeria: Engaging the Informal Economy in Post-2015 Development Agenda', Local Environment 22: 203-24.

Medina, M. (2007) The World's Scavengers: Salvaging for Sustainable Consumption and Production. Lanham, MD: AltaMira Press.

Nzeadibe, T.C. and P.O. Mbah (2015) 'Beyond Urban Vulnerability: Interrogating the Social Sustainability of a Livelihood in the Informal Economy of Nigerian Cities', Review of African Political Economy 42(144): 279-98.

Phillips, R. (2009) 'Food Security and Women's Health: A Feminist Perspective for International Social Work', International Social Work 52(4): 485-98.

Reyneke, P. (2016) 'Dumpsite Bricolage: The Responses of the Urban Waste Precariat to the Formalisation and Privatisation of Waste Management in the City of Tshwane', Master's Thesis, University of Pretoria, Pretoria, South Africa.

Riches, G. (2011) 'Thinking and Acting Out of the Charitable Box: Hunger and Right to Food in Rich Societies', International Social Work 21(4-5): 768-75.

Roberts, H.A. (2013) 'Landfills or Dump Sites? Status of Landfill Sites in the Free State Province, South Africa', Interim: Interdisciplinary Journal 12(1): 32-41. 
Samson, M. (2012) 'Wasting Value and Valuing Waste: Insights into the Global Crisis and Production of Value Reclaimed from a Soweto Garbage Dump', PhD Thesis, York University, Toronto, ON, Canada.

Schenck, C., D. Blaauw and K. Viljoen (2012) 'Unrecognised Waste Management Experts: Challenges and Opportunities for Small Business Development and Decent Job Creation in the Waste Sector in the Free State', Research Report for a Study Completed for the South African SME Observatory, Hosted by the Department of Economic Development, Tourism and Environmental Affairs of the Free State Province (DETEA) and the International Labour Organization (ILO), Geneva, 14 December.

Schenck, R. and D. Blaauw (2011a) 'Living on What Others Throw Away: An Exploration of the Socio-Economic Circumstances of People Collecting and Selling Recyclable Waste', The Social Work Practitioner-Researcher 23(2): 135-53.

Schenck, R. and D. Blaauw (2011b) 'The Work and Lives of Street Waste Pickers in Pretoria A Case Study of Recycling in South Africa's Urban Informal Economy', Urban Forum 22(4): 411-30.

Schenck, R., D. Blaauw and K. Viljoen (2016) 'Enabling Factors for the Existence of Waste Pickers: A Systematic Review', Social Work/Maatskaplike Werk 52(1): 35-53.

Sen, A. (1999) Development as Freedom. New York: Knopf.

Sentime, K. (2011) 'Profiling Solid Waste Pickers: A Case Study of Braamfontein - Greater Johannesburg', Africanus 41(2): 96-111.

Skinner, C. and G. Haysom (2016) 'The Informal Sector's Role in Food Security: A Missing Link in Policy Debates', Working Paper 44, PLAAS, UWC and CoE for Food Security, Cape Town, South Africa, 12 September 2016.

Statistics South Africa (2016) 'Work and Labour Force'. Available online at: http://www.statssa.gov. za/?page-id=737\&id=1 (accessed 8 July 2016).

Tacoli, C., B. Bukhari and S. Fisher (2013) 'Urban Poverty, Food Security and Climate Change', Working Paper 37, International Institute for Environment and Development, London. Available online at: http:// pubs.iied.org/pdfs/10623IIED.pdf (accessed 2 July 2016).

Terzi, L. (2007) 'The Capability to Be Educated', in M. Walker and E. Unterhalter (eds) Amartya Sen's Capability Approach and Social Justice in Education, pp. 25-43. London: Palgrave Macmillan.

Van Heerden, A. (2015) 'Valuing Waste and Wasting Value: Rethinking Planning with Informality by Learning from Skarrellers in Cape Town's Southern Suburbs', Master's Dissertation, University of Cape Town, Cape Town, South Africa.

Viljoen, J.M.M. (2014) 'Economic and Social Aspects of Street Waste Pickers in South Africa', $\mathrm{PhD}$ Thesis, University of Johannesburg, Johannesburg, South Africa.

\section{Author biographies}

Catherina J. Schenck is Professor in the Department of Social Work at the University of the Western Cape. She focuses her research on working conditions of social workers, poverty and unemployment, people in the informal economy, in particular day labourers and waste pickers. 
Phillip F. Blaauw is Professor in the School of Economics at the Potchefstroom Campus of North-West University. His research interests include labour economics, the informal economy and local economic development.

Jacoba M.M. Viljoen is Senior Lecturer in the School of Economics at the University of Johannesburg. Her research areas includes labour economics, informal labour markets, poverty, unemployment, and youth unemployment.

Elizabeth C. Swart is Associate Professor in the Department of Dietetics and Nutrition, University of the Western Cape. Her research area is Community nutrition and Public Health nutrition with a specific focus on Nutrition policy and programming to promote population health and prevent malnutrition and its consequences. She acts as programme leader for Nutrition and Health within the NRF/DST Centre of Excellence in Food Security which has been awarded to the University of the Western Cape in 2014 (in collaboration with University of Pretoria). 